Katarzyna Pawlak

Wojskowa Akademia Techniczna, Warszawa, Polska - Military University of Technology, Warszawa, Poland

Anna DZIADKIEWICZ

Uniwersytet Gdański, Polska • University of Gdansk, Poland

\title{
Wpływ działań CSR w przemyśle odzieżowym na akceptację wyższej ceny przez konsumentów pokolenia Z
}

\section{Influence of CSR Activities in Fashion Industry on Generation Z Customers' Willingness to Accept a Higher Price}

Streszczenie: Celem artykułu było zbadanie, czy stosunek młodych konsumentów do zakupów odzieży wytwarzanej przez firmy prowadzące działania społecznej odpowiedzialności biznesu (CSR) może wpływać na akcentację wyższych cen tych produktów. Badanie zostało przeprowadzone na próbie 150 respondentów, reprezentujących pokolenie Z. Do weryfikacji hipotez badawczych zastosowano jednoczynnikową analizę wariancji. Wyniki badania pokazują, iż istnieje związek pomiędzy pozytywnym stosunkiem pokolenia $\mathrm{Z}$ do zakupu odzieży produkowanej zgodnie $\mathrm{z}$ zasadami CSR a wysokością akceptowanych przez nie cen. Konsumenci o pozytywnych postawach akceptują wyższy poziom cen ubrań produkowanych społecznie odpowiedzialnie. Wyniki badania są istotne dla polskiej praktyki gospodarczej i mogą być zachętą do podejmowania działań z zakresu CSR przez przedsiębiorstwa. Ma to szczególnie duże znaczenie obecnie, kiedy to głównie duże przedsiębiorstwa wdrażają omawianą koncepcję. Artykuł wypełnia lukę w badaniach zachowań polskich konsumentów pokolenia $\mathrm{Z}$ na rynku odzieży produkowanej zgodnie z zasadami CSR. Przyczynia się także do zrozumienia działań społecznie odpowiedzialnych, zarówno przez młodych konsumentów, jak i przez firmy odzieżowe. Wskazano jednak konieczność prowadzenia dalszych badań nad omawianym tematem.

\begin{abstract}
The purpose of this paper is to examine whether the attitude of customers representing generation $\mathrm{Z}$ towards the purchase of clothing manufactured by enterprises acting according to CSR concept can have an influence on them accepting a higher price of the goods. In total, 150 respondents participated in the survey. A confirmatory factor analysis was conducted to check the validity and reliability of the data obtained. Hypotheses were tested using the one-way analysis of variance. The findings showed a relationship between a positive attitude of the generation $\mathrm{Z}$ towards purchasing clothing manufactured by the enterprises acting according to the CSR concept and them accepting a higher price. The $Z$ customers with positive attitude accept a higher price of clothing produced according to CSR principles. The research results are important to Polish economy and can encourage many enterprises to implement CSR. It is essential nowadays as only large enterprises try to implement CSR activities. The paper contributes to research by advancing the understanding on how consumers make CSR decisions when purchasing clothing and spreads knowledge about CSR activities both to customers and enterprises. Limitations and directions for future research are presented in the article.
\end{abstract}


Słowa kluczowe: pokolenie Z; przemysł odzieżowy; społeczna odpowiedzialność biznesu; zachowania konsumentów; zrównoważona konsumpcja

Keywords: consumer behaviour; corporate social responsibility; fashion industry; generation Z; sustainable consumption

Otrzymano: 7 maja 2019

Received: 7 May 2019

Zaakceptowano: 30 września 2019

Accepted: 30 September 2019

\section{Sugerowana cytacja/Suggested citation:}

Pawlak, K., Dziadkiewicz, A. (2019). Wpływ działań CSR w przemyśle odzieżowym na akceptację wyższej ceny przez konsumentów pokolenia Z. Przedsiębiorczość - Edukacja [Entrepreneurship Education], 15(2), 139-152. doi: 10.24917/20833296.152.10

\section{Wstęp}

Koncepcja społecznej odpowiedzialności biznesu (CSR) rozwijana pod koniec XX w. budzi kontrowersje $\mathrm{w}$ nauce i w praktyce gospodarczej. Jej przeciwnicy twierdzą, iż przedsiębiorstwa nie mają obowiązku realizowania celów społecznych, a takie działania uznają za szkodliwe dla biznesu i akcjonariuszy (Friedman, 1970). Zmiany technologiczne i społeczne, które nastąpiły na początku XXI w., spowodowały, iż wzrosły oczekiwania różnych grup w otoczeniu przedsiębiorstwa (Freeman, 2010). Odpowiedzią części przedsiębiorstw na te oczekiwania było włączanie, choćby fragmentaryczne, działań społecznie odpowiedzialnych do strategii firm oraz informowanie opinii publicznej o tym fakcie.

Ze względu na wielość definicji i częste mylenie koncepcji społecznej odpowiedzialności biznesu z odpowiedzialną produkcją oraz odpowiedzialnym łańcuchem dostaw, warto przybliżyć różnice występujące pomiędzy tymi terminami. CSR w ujęciu ekonomicznym można zdefiniować jako „efektywną strategię zarządzania, która poprzez prowadzenie dialogu społecznego na poziomie lokalnym przyczynia się do wzrostu konkurencyjności przedsiębiorstw na poziomie globalnym i jednocześnie kształtuje korzystne warunki dla rozwoju społecznego i ekonomicznego" (Rok, 2004: 17), z kolei zrównoważona produkcja prowadzi do zwiększenia korzyści netto z działalności gospodarczej poprzez zmniejszenie zużycia środków oraz zmniejszenie skali degradacji i zanieczyszczeń, co jednocześnie poprawia jakość życia. Zrównoważona konsumpcja i produkcja wymagają systematycznego podejścia i współpracy podmiotów uczestniczących w całym łańcuchu dostaw, począwszy od producentów, a skończywszy na konsumentach. Proces ten zakłada prowadzenie m.in. działań edukacyjnych dla konsumentów, mających podnieść ich świadomość na temat zrównoważonej konsumpcji, m.in. przez prowadzenie akcji informacyjnych na temat standardów i oznakowania produktów.

Celem niniejszego artykułu jest zbadanie, czy stosunek konsumentów reprezentujących pokolenie $Z$ do zakupów odzieży wytwarzanej przez firmy realizujące działania CSR może wpływać na akcentację przez nich wyższych cen tych produktów. Świadomi konsumenci bowiem w sytuacji, gdy jakość i cena produktów są zbliżone, preferują produkty wytwarzane w sposób odpowiedzialny (Bhattacharya, Sen, Korschun, 2011). Należy zauważyć, iż wzrost świadomości konsumenckiej nie zawsze przekłada się na akceptację 
przez konsumentów wyższych cen (Young i in., 2010). Konsumenci, mimo iż oczekują produktów wyższej jakości produkowanych zgodnie ze standardami CSR, nie chcą z tego tytułu ponosić dodatkowych kosztów, lecz oczekują, iż cena produktu będzie zbliżona do ceny produktu tradycyjnego (Hajdas, 2013; Zgoda, 2015).

Przyczyną takiego stanu może być większa dostępność towarów produkowanych zgodnie z zasadami CSR uznawanymi przez część konsumentów za obowiązujący na rynku standard (Hajdas, 2013). Innym powodem może być nieufność konsumentów w stosunku do komunikatów o działaniach CSR, które konsumenci traktują wyłącznie jako działania wizerunkowe. Wprowadzenie jednak przez przedsiębiorstwa zmian w zakresie organizacji produkcji i relacji z dostawcami wiąże się ze zwiększonymi kosztami (Berger-Grabner, 2018). Nie wszystkie mogą być redukowane przez innowacje ekologiczne i oszczędności związane z mniejszym zużyciem surowców, energii i wody. Istotne jest zatem zbadanie, czy klienci, oczekujący produktów zgodnych z koncepcją CSR, będą skłonni ponieść z tego tytułu wyższe koszty i zaakceptować wyższą cenę produktu w stosunku do produktu tradycyjnego. Problem ten stał się przedmiotem badania przeprowadzonego wśród konsumentów pokolenia Z w marcu 2019 r.

\section{Działania społecznie odpowiedzialne w przemyśle odzieżowym}

Koncepcja CSR oznacza, iż organizacja dobrowolnie ponosi odpowiedzialność za wpływ swoich działań na społeczeństwo i środowisko. Działania te powinny przyczyniać się do zrównoważonego rozwoju, dobrobytu społeczeństwa oraz uwzględniać oczekiwania interesariuszy (Marcinkowska, 2010). Do kluczowych obszarów aktywności firm w zakresie realizacji koncepcji CSR należą (ISO 26 000):

- prawa człowieka - praktyki w miejscu pracy, polegające np. na niedyskryminowaniu pracowników, przestrzeganiu prawa pracy, standardów bezpieczeństwa i higieny pracy, zakazu zatrudniania dzieci i pracy przymusowej;

- zarządzanie zasobami ludzkimi - polegające na zapewnieniu pracownikom odpowiednich warunków pracy i możliwości rozwoju;

- dbanie o środowisko naturalne - odpowiedzialne gospodarowanie zasobami, odpadami, minimalizowanie wpływu na środowisko naturalne oraz podejmowanie działań na rzecz środowiska naturalnego, np. ograniczenie używania szkodliwych barwników zawierających metale ciężkie, wykorzystanie surowców w mniejszym stopniu obciążających środowisko (pinatex, włókna bambusowe);

- uczciwe praktyki biznesowe - prowadzenie działalności zgodnie z prawem i zasadami etycznymi;

- sprawy konsumenckie - dbanie o bezpieczeństwo produktów, uczciwą komunikację, edukowanie konsumentów np. na temat konserwacji odzieży;

- zaangażowanie w rozwój społeczeństwa - działania na rzecz poprawy poziomu życia społecznego, w tym wspieranie lokalnych społeczności, edukacja oraz współpraca z lokalnymi kontrahentami;

- zarządzanie organizacją - prowadzenie działalności gospodarczej w sposób etyczny, zgodny z prawem i transparentny.

Z uwagi na ogromne znaczenie outsourcingu produkcyjnego działań CSR w przemyśle odzieżowym nie należy rozpatrywać wyłącznie w stosunku do samego przedsiębiorstwa odzieżowego, lecz w odniesieniu do całego łańcucha dostaw. Celem tego zabiegu jest 
kształtowanie odpowiedzialnego cyklu życia produktu. CSR w przemyśle odzieżowym obejmuje zatem poszczególne etapy powstawania produktu: od pozyskiwania surowców (np. bawełny), przez wytwarzanie tkanin, szycie, do dystrybucji i sprzedaży (Rudnicka, 2016). Co więcej, można zaobserwować również początki angażowania się producentów w recykling nieużywanych ubrań oraz edukację klientów.

Do obszarów z zakresu CSR ważnych dla przedsiębiorstw odzieżowych zaliczyć należy:

- odpowiedzialność finansową (np. regulacja kwestii związanych z wynagrodzeniami pracowników i dostawców, płacą minimalną, publikacją raportów na temat informacji finansowych i pozafinansowych, nieunikanie opodatkowania);

- odpowiedzialność społeczną i etyczną (przyjęcie dobrowolnie kodeksów etycznych, określających m.in. zasady postępowania z dostawcami, w których pojawiają się zapisy dotyczące warunków pracy i sprawiedliwej płacy u podwykonawców, zasady prowadzenia u nich kontroli, poprawy jakości produktów, przestrzeganie wytycznych opracowywanych przez międzynarodowe organizacje i stowarzyszenia, wspieranie lokalnych społeczności przez wsparcie finansowe i rzeczowe, prowadzenie komunikacji z otoczeniem w sposób transparenty i uczciwy);

- odpowiedzialność środowiskową (rezygnacja z tkanin i materiałów niebezpiecznych dla środowiska, takich jak poliester, lub których pozyskiwanie wiąże się z cierpieniem zwierząt - np. naturalne futra - oraz ograniczenie w procesie produkcyjnym szkodliwych substancji, zmniejszenie ilości odpadów i zużycia wody, wprowadzenie programów edukujących konsumentów i współpraca z organizacjami proekologicznymi).

Społecznie odpowiedzialne przedsiębiorstwa odzieżowe powinny uwzględniać potrzeby różnych grup interesariuszy w całym łańcuchu dostaw, włączając w to pracowników produkcji, sprzedaży i konsumentów (Palewicz, Baran, 2012). Z uwagi na fakt, iż nawet mniejsze firmy odzieżowe współpracują z tysiącami dostawców, liczba i międzynarodowy zasięg poszczególnych grup interesariuszy stają się dużym wyzwaniem dla firm odzieżowych. Z tego powodu mniejsze firmy odzieżowe ograniczają działania CSR do pracowników i społeczności lokalnych. Dużą rolę odgrywają w tym więc sami konsumenci, którzy niejednokrotnie potrafią wpłynąć na zmianę polityki przedsiębiorstwa. Przykładem takiego działania może być bojkot polskiej firmy odzieżowej LPP przez klientów w 2013 i 2014 r.

\section{Odpowiedzialne (zrównoważone) zachowania młodych konsumentów na rynku odzieżowym}

Kryzys gospodarczy, który wystąpił w 2008 r., przyniósł wiele zmian we wzorach zakupowych młodych konsumentów. Z obawy przed recesją konsumenci zaczęli racjonalizować swoje wydatki konsumpcyjne, modny stał się oszczędny, zdrowy styl życia, a znaczenie konsumpcji w systemie wartości uległo gwałtownemu obniżeniu (Sobczyk, 2014). Wzrosła również świadomość konsumentów na temat problemów społecznych i ekologicznych, a także działań podejmowanych przez władze centralne i lokalne oraz same przedsiębiorstwa (Black, 2010). Zmiany te sprzyjają rozwojowi zrównoważonej (odpowiedzialnej) konsumpcji oraz społecznej odpowiedzialności biznesu. 
Odpowiedzialna konsumpcja oznacza, iż konsumenci, podejmując decyzje nabywcze, dążą do zaspokojenia swoich potrzeb z równoczesnym uwzględnieniem kwestii społecznych i środowiskowych. Odpowiedzialna konsumpcja polega na podejmowaniu przez konsumenta odpowiedzialnych decyzji w całym cyklu konsumpcji: w procesie zakupu, użytkowania i pozbywania się zużytych produktów.

W przypadku konsumpcji odzieży będą to działania zmierzające m.in. do:

- ograniczenia pod względem ilościowym zakupów odzieży - dotyczy to zakupów tanich, jednosezonowych, o niskiej jakości i trwałości, tzw. fast fashion, a także zakupu, wypożyczania lub wymiany odzieży używanej,

- zwiększenia racjonalności konsumenta w trakcie zakupu - umożliwia to wzrost zakupów przemyślanych przez wcześniejsze poszukiwanie informacji na temat kupowanych ubrań i ich producentów, porównywanie ofert, korzystanie z rekomendacji, sprawdzanie składu oraz warunków reklamacji oraz ograniczanie zakupów pod wpływem impulsu,

- wyboru produktów minimalizujących niekorzystny wpływ na środowisko i społeczeństwo przez wybór ubrań od lokalnych dostawców, szytych z tkanin naturalnych oraz mających certyfikaty (np. Fair Trade, GOTS - Global Organic Textile Standard, Ecolabel, ISO 9001, ISO 14001, Seria AA1000),

- wyboru producentów prowadzących działania CSR w zakresie ochrony środowiska i zarządzania kapitałem ludzkim w całym łańcuchu dostaw oraz wspierających działania społeczności lokalnych (sponsoring lokalnych drużyn sportowych, wspieranie edukacji czy też programów pomocy społecznej),

- konserwowania i pozbywania się odzieży we właściwy sposób - naprawianie, przerabiane lub przekazanie w użytkowanie innych konsumentom, odpłatnie (sprzedaż np. na allegro) lub bezpłatnie (oddanie rodzinie, znajomym, ubogim),

- bojkotu producentów naruszających zasady CSR - wstrzymywanie się od zakupów od producentów postępujących nieetycznie oraz informowanie o tym fakcie innych konsumentów.

Niestety, wraz z realizacją wymienionych wyżej działań, rosną także koszty ponoszone przez konsumenta (wyższe ceny, racjonalność, czas poświęcany na poszukiwanie właściwych informacji oraz innych sposobach konsumpcji).

\section{Metodyka badania i charakterystyka próby badawczej}

Zachowania społecznie odpowiedzialne konsumentów na rynku odzieżowym stały się przedmiotem badania przeprowadzonego na próbie młodych konsumentów (pokolenie Z), będących studentami jednej z warszawskich uczelni wyższych. W badaniu wzięły udział 153 osoby ${ }^{1}$. Wśród nich 54,7\% stanowiły kobiety, a 45,3\% mężczyźni. Większość badanych deklarowała przeciętną lub dobrą sytuację finansową.

Dane zostały zebrane metodą ankiety audytoryjnej z wykorzystaniem wystandaryzowanego kwestionariusza, który składał się z pytań dotyczących m.in. zachowań społecznie odpowiedzialnych konsumentów na rynku odzieżowym, ich stosunku do przedsiębiorstw podejmujących działania CSR oraz zakupów (skala Likerta). Respondentów poproszono również o podanie akceptowanej przez nich ceny koszulki T-shirt produkowanej zgodnie

\footnotetext{
${ }^{1} \mathrm{~W}$ trakcie redakcji odrzucono trzy kwestionariusze $\mathrm{z}$ uwagi na dużą liczbę brakujcych odpowiedzi.
} 
z zasadami CSR (z organicznej bawełny z poszanowaniem zasad uczciwego handlu). Jako punkt odniesienia dla respondentów podano cenę podobnej koszulki produkowanej w sposób uznany za tradycyjny. Do interpretacji wyników wykorzystano pakiet statystyczny SPSS 22.

Głównym celem badania była ocena, czy preferencje konsumentów, w stosunku do zakupów odzieży wytwarzanej przez firmy realizujące działania CSR, mogą wpływać na akcentację wyższych cen tych produktów.

Postawiono również cele szczegółowe, dotyczące następujących zagadnień:

- czy konsumenci interesują się kwestiami społecznymi i środowiskowymi, kiedy kupują odzież, oraz które kwestie są dla nich istotne,

- jaki jest stosunek respondentów do podejmowanych przez nich działań z zakresu odpowiedzialnej konsumpcji oraz do działań CSR producentów odzieży,

- jaki jest stosunek respondentów do zakupów odzieży produkowanej zgodnie z zasadami CSR.

Przyjęto także dwie hipotezy badawcze:

- Preferencje konsumentów w stosunku do nabywanych ubrań, wytwarzanych zgodnie z zasadami CSR, mają wpływ na poziom akceptowanych cen tych produktów.

- Konsumenci o pozytywnym stosunku do nabywanych ubrań, produkowanych zgodnie z zasadami CSR, akceptują wyższy poziom cen.

W celu przetestowania hipotez, przeprowadzono jednoczynnikową analizę wariancji w planie dla grup niezależnych wraz z analizą kontrastów. Zmienną objaśniającą była cena podawana przez respondentów, którą byliby skłonni zapłacić za T-shirt z organicznej bawełny, wytwarzany z poszanowaniem zasad uczciwego handlu. Natomiast czynnikiem różnicującym, jakościowym - deklarowany przez respondentów stosunek (negatywny, obojętny i pozytywny) do odzieży, produkowanej w przedsiębiorstwach korzystających z koncepcji CSR.

\section{Wyniki badania}

Zdaniem wielu autorów warunkiem zaistnienia zrównoważonej konsumpcji jest wzrost świadomości ekologicznej i społecznej konsumentów (Bhattacharya, Sen, Korschun, 2011, Bylok, 2018), który winien wyrażać się nie tylko zwiększoną świadomością konsumentów, ale również określoną postawą i podejmowanymi przez nich działaniami.

W badanej próbie większość respondentów deklarowała, iż przy zakupie odzieży zwraca uwagę na kwestie społeczne i ekologiczne, związane m.in. z miejscem wytwarzania ubrań $(39,3 \%$ odpowiedzi) oraz rzetelnym i uczciwym komunikowaniem się z klientami (ok. 31,3\%). Respondentów interesowały również działania firm odzieżowych podejmowane na rzecz ochrony środowiska, np. ograniczenie zużycia wody, materiałów i energii (18\%) oraz użycia szkodliwych substancji w procesie produkcyjnym (27,3\%). Istotne dla respondentów były również informacje o warunkach pracy w całym łańcuchu dostaw (18,7\%), preferowanie lokalnych dostawców (4\%) oraz nieużywanie futer w produkcji odzieży (24,7\%). Część respondentów była zainteresowana działaniami przedsiębiorstw na rzecz społeczności lokalnych: wspieraniem sportu, edukacji i sztuki (16,7\%). Co czwarty konsument deklarował, iż nie interesuje się w ogóle działaniami CSR. Powyższe wyniki zaprezentowano w tabeli 1 . 
Tabela 1. Czynniki wpływające na wybór produktu

\begin{tabular}{|l|c|c|}
\hline \multicolumn{1}{|c|}{$\begin{array}{c}\text { Istotne dla konsumenta informacje o firmie } \\
\text { i jej produktach (poza ceną) }\end{array}$} & Częstotliwość & Procent odpowiedzi \\
\hline Kraj produkcji odzieży & 59 & $39,3 \%$ \\
\hline $\begin{array}{l}\text { Komunikacja prowadzona w sposób uczciwy } \\
\text { i rzetelny }\end{array}$ & 47 & $31,3 \%$ \\
\hline $\begin{array}{l}\text { Używanie przy produkcji substancji szkodliwych } \\
\text { dla środowiska i zdrowia ludzi }\end{array}$ & 41 & $27,3 \%$ \\
\hline Rezygnacja z naturalnych futer & 37 & $24,7 \%$ \\
\hline Dbanie o warunki pracy pracowników & 28 & $18,7 \%$ \\
\hline $\begin{array}{l}\text { Dbanie o środowisko podczas produkcji odzieży } \\
\text { (zużycie wody, recykling) }\end{array}$ & 27 & $18,0 \%$ \\
\hline $\begin{array}{l}\text { Finansowe wsparcie społeczności lokalnych } \\
\text { (sponsorowanie sportu, edukacji, sztuki) }\end{array}$ & 25 & $16,7 \%$ \\
\hline Współpraca z lokalnymi kontrahentami & 6 & $4,0 \%$ \\
\hline Inne & 2 & $1,3 \%$ \\
\hline $\begin{array}{l}\text { Respondenta nie interesują kwestie społeczne, } \\
\text { gdy kupuje odzież }\end{array}$ & 38 & $25,3 \%$ \\
\hline
\end{tabular}

Źródło: opracowanie własne na podstawie przeprowadzonego badania

W pytaniu o stosunek respondentów do CSR i uwzględnianie kwestii społecznych i środowiskowych posłużono się pięciostopniową skalą Likerta, zawierającą dziewięć stwierdzeń. Odpowiedzi respondentów zaprezentowano w tabeli 2 i na rycinie 1 . Wskaźnik alfa-Cronbacha skali wyniósł 0,712 . Prezentowane na wykresie wyniki pozwoliły ocenić, jaki jest udział respondentów, którzy mają przychylne nastawienie do działań z zakresu zrównoważonej konsumpcji i działań CSR.

Duża część respondentów zadeklarowała podejmowanie różnych działań na rzecz zrównoważonej konsumpcji, m.in. sprawdzanie rodzaju użytych tkanin (ponad 70\%) i miejsca produkcji (35\%) oraz pierwszeństwo w zakupie ubrań lepszej jakości, lecz w mniejszej liczbie (ponad 65\%). Co trzeci badany zadeklarował również nabywanie odzieży używanej. Co piąty respondent zadeklarował, iż kupuje ubrania polskich marek i od polskich projektantów lub takich, którzy posiadają certyfikaty, świadczące o działaniach CSR.

Na skali znalazły się również stwierdzenia umożliwiające określenie, czy działania CSR prowadzone przez firmy wpływają na wybory konsumenckie oraz opinie o firmie. Co trzeci respondent zgodził się ze stwierdzeniem, że prowadzenie działań CSR przez firmy odzieżowe wpływa na jego opinię o tych firmach i sprawia, że chętniej kupuje produkowane przez nie produkty. Natomiast prawie 20\% respondentów unika zakupów od producentów działających nieetycznie.

Zidentyfikowanie respondentów o różnym stosunku do kupowania ubrań produkowanych zgodnie z zasadami CSR pozwoliło na przetestowanie hipotezy badawczej o wpływie stosunku konsumentów (negatywny, obojętny i pozytywny) do zakupu dóbr, produkowanych zgodnie z zasadami CSR, na akceptację wyższej ceny produktu (cena T-shirtu wyrażona w złotych). W tym celu przeprowadzono jednoczynnikową analizę 


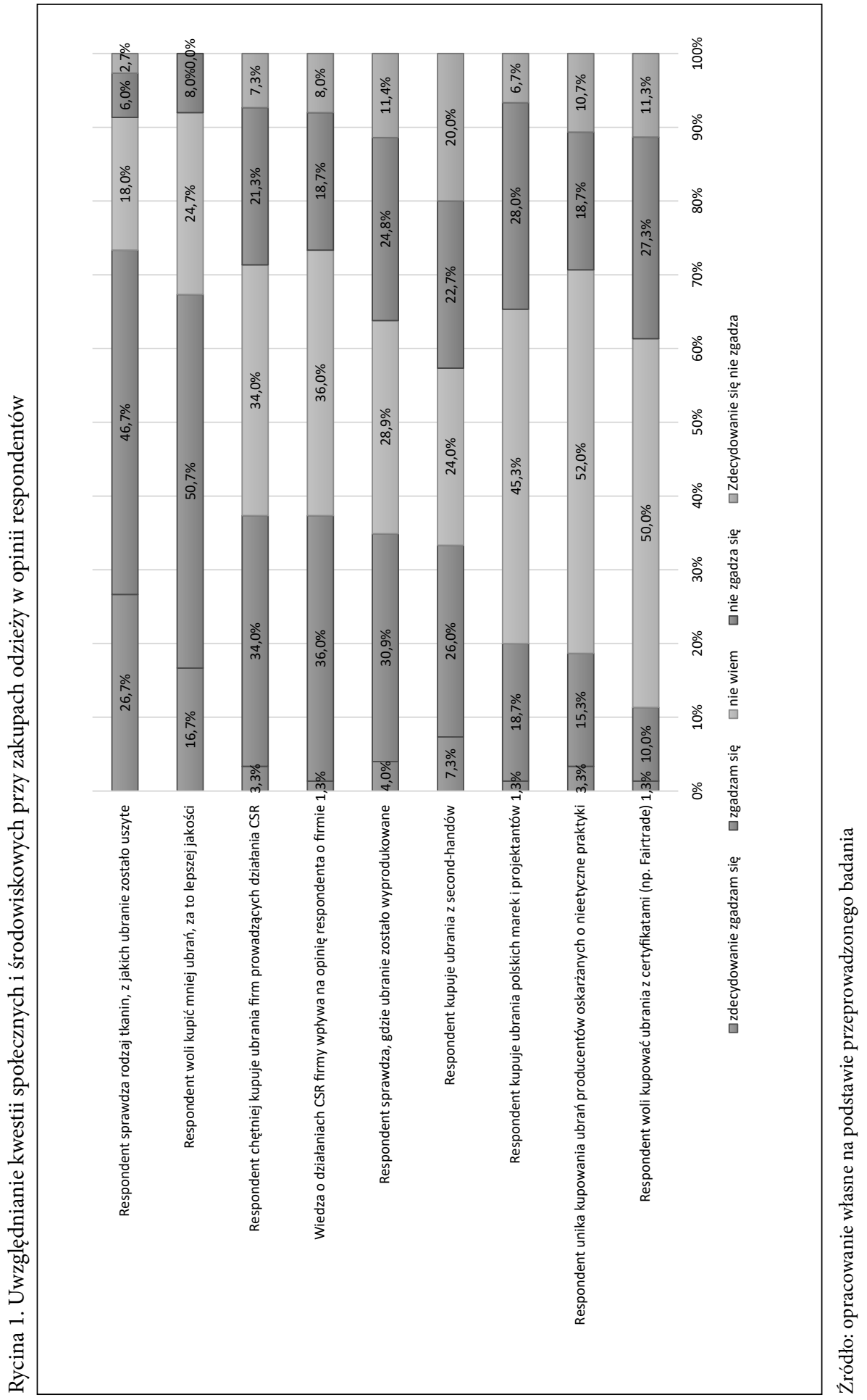


wariancji w planie dla grup niezależnych ${ }^{2}$. W wyniku analizy uzyskano istotny statystycznie efekt wpływu zmiennej na wysokość akceptowanej ceny $\mathrm{F}(2,142)=5,086 ; \mathrm{p}<0,01$ (por. tabela 3).

Tabela 2. Kwestie społeczne i środowiskowe a zakupy odzieży w opinii respondentów

\begin{tabular}{|l|c|c|c|}
\hline \multicolumn{1}{|c|}{$\begin{array}{c}\text { Uwzględnianie kwestii społecznych } \\
\text { i środowiskowych przez respondentów przy } \\
\text { zakupach odzieży }\end{array}$} & Średnia & Mediana & $\begin{array}{c}\text { Odchylenie } \\
\text { standardowe }\end{array}$ \\
\hline $\begin{array}{l}\text { Preferencje w zakupie ubrań firm prowadzących } \\
\text { działania CSR }\end{array}$ & 3,05 & 3 & 0,992 \\
\hline $\begin{array}{l}\text { Unikanie zakupów ubrań producentów } \\
\text { oskarżanych o nieetyczne praktyki }\end{array}$ & 2,82 & 3 & 0,935 \\
\hline $\begin{array}{l}\text { Wpływ wiedzy o działaniach CSR na opinię } \\
\text { o firmie }\end{array}$ & 3,04 & 3 & 0,962 \\
\hline Sprawdzanie rodzaju tkanin & 3,89 & 4 & 0,959 \\
\hline $\begin{array}{l}\text { Preferencje w zakresie zakupu mniejszej liczby } \\
\text { ubrań, za to lepszej jakości }\end{array}$ & 3,76 & 4 & 0,825 \\
\hline Miejsce produkcji & 2,91 & 3 & 1,084 \\
\hline $\begin{array}{l}\text { Preferencje w zakresie zakupu ubrań polskich } \\
\text { marek i projektantów }\end{array}$ & 2,80 & 3 & 0,867 \\
\hline $\begin{array}{l}\text { Preferencje w zakresie zakupu ubrań z second- } \\
\text { handu }\end{array}$ & 2,78 & 3 & 1,242 \\
\hline $\begin{array}{l}\text { Preferencje w zakresie zakupu ubrań } \\
\text { z certyfikatami }\end{array}$ & 2,63 & 3 & 0,863 \\
\hline
\end{tabular}

Źródło: opracowanie własne na podstawie przeprowadzonego badania

Tabela 3. Średnie wartości cen akceptowanych przez respondentów

\begin{tabular}{|l|c|c|c|c|c|}
\hline $\begin{array}{c}\text { Stosunek do zakupów } \\
\text { odzieży produkowanych } \\
\text { w sposób społecznie } \\
\text { odpowiedzialny }\end{array}$ & $\mathbf{N}$ & Średnia & $\begin{array}{c}\text { Odchylenie } \\
\text { standardowe }\end{array}$ & Min & Max \\
\hline Stosunek negatywny & 41 & 60,171 & 14,565 & 20 & 90 \\
\hline Stosunek obojętny & 50 & 59,740 & 16,372 & 25 & 100 \\
\hline Stosunek pozytywny & 52 & 69,010 & 16,444 & 30 & 100 \\
\hline Ogółem & 143 & 63,234 & 16,389 & 20 & 100 \\
\hline $\begin{array}{l}\text { P anova (współczynnik } \\
\text { testowy p analizy wariancji } \\
\text { Anova) }\end{array}$ & $\begin{array}{c}\mathrm{F}(2,140)=5,396 ; \\
\mathrm{p}<0,006\end{array}$ & & & & \\
\hline
\end{tabular}

\footnotetext{
${ }^{2}$ Spełnione zostało założenie o jednorodności wariancji dla danych nieprzekształconych $(\mathrm{F}(2,140)=0,122 ; \mathrm{ni}$. oraz założenie, iż grupy nie różnią się istotnie statystycznie pod względem liczebności $(\chi 2(2)=1,72$; ni). Niespełnione zostało założenie o normalności rozkładu w poszczególnych grupach. W celu wyeliminowania wpływu wartości odstających na średnie usunięto wartości odstające w grupie drugiej i trzeciej (o obojętnym i pozytywnym nastawieniu do CSR), które znacząco wpłynęłyby na wyniki średniej.

${ }^{3}$ Zakupy w sklepach z używaną odzieżą (tzw. second-handach) to przykład realizowania najbardziej doskonałej formy recyklingu, tzw. recyklingu pierwotnego, recyklingu pętli zamkniętej.
} 
Rycina 2. Stosunek respondentów do kupowania ubrań produkowanych zgodnie z zasadami CSR

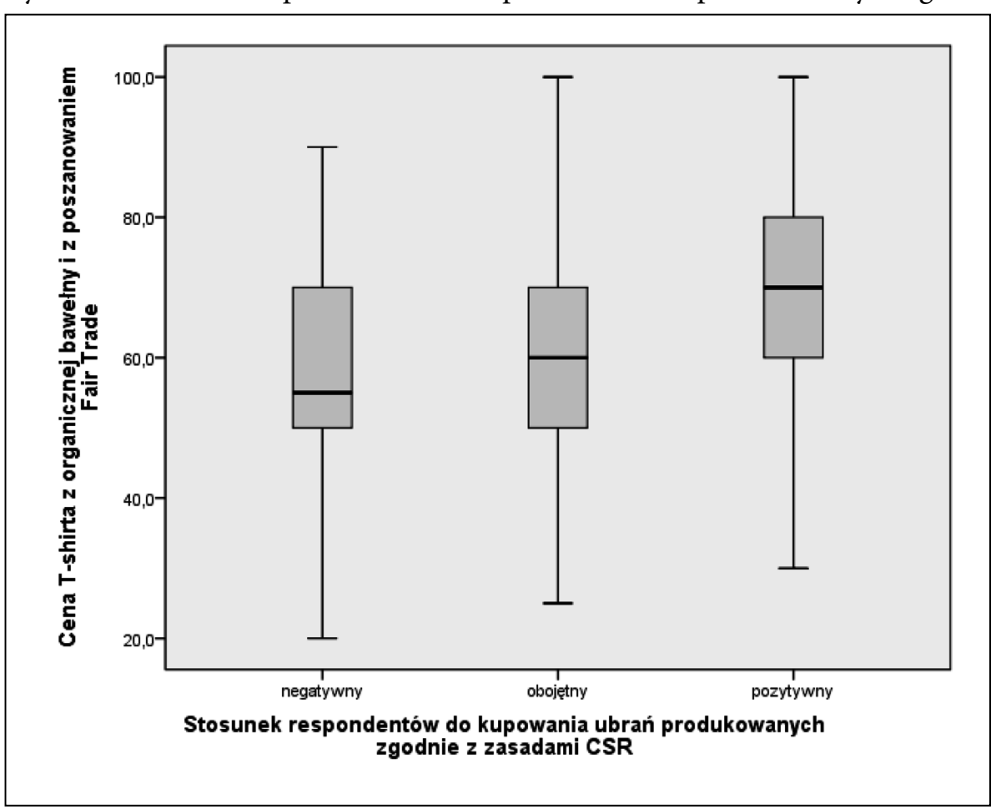

Źródło: opracowanie własne na podstawie przeprowadzonego badania

Porównania za pomocą testu Scheffego post hoc ujawniły istotne statystycznie różnice między grupą o pozytywnym nastawieniu wobec działań CSR oraz pozostałymi grupami $(\mathrm{p}<0,005)$. Nie stwierdzono istotnie statystycznie różnic pomiędzy grupami deklarujących obojętny i negatywny stosunek do zakupów odzieży produkowanej zgodnie z zasadami CSR.

Najwyższe ceny wskazywali respondenci, deklarujący pozytywny stosunek do wyboru produktów produkowanych zgodnie z zasadami CSR $(\mathrm{M}=69,972 \mathrm{zł})$, niższe ceny wskazywali respondenci o obojętnym stosunku $(M=60,922)$ i negatywnym $(M=60,171)$.

W celu weryfikacji drugiej hipotezy badawczej wykonano również testy kontrastów, dzięki którym okazało się, że respondenci o pozytywnym stosunku do zakupów odzieży, produkowanej zgodnie z zasadami CSR, będą skłonni akceptować wyższe ceny. Wyniki kontrastu, przy założeniu jednorodności wariancji, okazały się istotne statystycznie $\mathrm{t}(142)=3,19 ; \mathrm{p}<0,005$. Oznacza to, że grupa o pozytywnym stosunku różni się od pozostałych dwóch grup (o stosunku negatywnym i obojętnym) traktowanych łącznie, a średnia cena $(M=69,97)$ T-shirta wynosi więcej niż średnia w obu pozostałych grupach.

Na podstawie uzyskanych wyników można wnioskować, iż respondenci, którzy deklarowali, iż wolą kupować ubrania produkowane przez firmy prowadzące różnorodne działania CSR, są również skłonni nagradzać te firmy za ponoszenie dodatkowych kosztów finansowych i organizacyjnych, związanych z realizacją koncepcji CSR w łańcuchach dostaw. Wyniki badania są sprzeczne $\mathrm{z}$ formułowanymi opiniami, iż konsumenci doceniają produkty produkowane zgodnie z zasadami CSR i preferują je w stosunku do tradycyjnych produktów, natomiast nie są skłonni zapłacić za nie wyższej ceny.

Wyniki badania pozwoliły pozytywne zweryfikować postawioną w pracy hipotezę. Należy jednak pamiętać, że wyniki oparte są jedynie na deklaracjach konsumentów, dlatego 
należałoby je potwierdzić w eksperymentach rynkowych, mierzących rzeczywiste wydatki konsumentów na odzież. Bezsprzecznie wyniki badania są istotne dla polskiej praktyki gospodarczej i mogą być zachętą do podejmowania przez przedsiębiorstwa działań CSR.

W nauce dyskusja, dotycząca sensu podejmowania działań CSR, zdominowana jest przez rozważania dotyczące wpływu tych działań na realizację celów biznesowych przedsiębiorstw. Istotną rolę w zmianie postrzegania odegrała zwłaszcza teoria interesariuszy, kontraktu społecznego, szkoła zasobowa i pozycyjna (Stefańska, 2013). Teorie te podkreślają znaczenie relacji przedsiębiorstwa $\mathrm{z}$ grupami otoczenia. Teoria kontraktu społecznego przyrównuje relacje przedsiębiorstwa do umowy ze społeczeństwem. Przedsiębiorstwo, korzystając z zasobów danego społeczeństwa, przyjmuje na siebie określone zobowiązania (np. respektowanie prawa, kultury lokalnej, płacenie podatków) (Carroll, 2004). Teoria interesariuszy wskazuje konkretne grupy w otoczeniu przedsiębiorstwa, których oczekiwania przedsiębiorstwa powinny uwzględniać, np. przez działania CSR, gdyż dzięki temu mogą uzyskać ich przychylność dla swoich działań. Efektem lepszych relacji z interesariuszami może być chociażby wzrost lojalności klientów, akcjonariuszy czy pracowników oraz przychylność władz lokalnych. Relacje te przyczyniają się do stabilizowania pozycji przedsiębiorstwa (Godfrey, Merrill, Hansen, 2009), ułatwiają pozyskiwanie nowych partnerów biznesowych, obniżają koszty pozyskiwania nowych klientów i kontrahentów oraz kapitału (Soppe, 2004). W teorii zasobowej i pozycyjnej, działania CSR mogą służyć do tworzenia innowacyjnych produktów i przewagi konkurencyjnej (Porter, Kramer, 2006).

Większość autorów jest zdania, iż nakłady na wdrażanie CSR należy traktować jako długookresową inwestycję (Kumar, Christodoulopoulou, 2013; Menz, 2010) i wskazują dwa sposoby, w jaki CSR może przyczyniać się do realizacji celów przedsiębiorstwa: bezpośrednio poprzez zmniejszenie kosztów (na skutek bardziej efektywnego wykorzystania zasobów) i pośrednio - poprzez oddziaływanie na interesariuszy (Bhattacharya, Sen, Korschun, 2011; Gomez-Bezares, Przychodzen, F., Przychodzen, J., 2016; Porter, Kramer, 2011).

Interesariusze świadomi działań przedsiębiorstwa w zakresie CSR mogą zwiększać swoją lojalność w stosunku do przedsiębiorstwa, np. chętniej inwestować w akcje firmy (Gomez-Bezaresi, Przychodzen, F., Przychodzen, J., 2016), kupować jej produkty czy aplikować na oferowane stanowiska pracy (Phillips i in. 2007). W przeciwnym wypadku, gdy przedsiębiorstwo postępuje nieetycznie, mogą rezygnować z oferty przedsiębiorstwa na rzecz konkurencji.

Do głównych grup nacisku na przedsiębiorstwa poza akcjonariuszami, władzami lokalnymi i organizacjami społecznymi, należą klienci. Trwałe pozytywne relacje z tą grupą stanowią istotny kapitał przedsiębiorstwa, wpływający na wzmocnienie wizerunku przedsiębiorstwa, wzrost sprzedaży produktów i większą odporność klientów na działania konkurentów.

\section{Zakończenie}

Masowa produkcja tanich ubrań implikuje powstawanie wielu problemów środowiskowych i społecznych w łańcuchu dostaw. Dotyczą one naruszania norm w zakresie ochrony środowiska czy łamania praw pracowniczych w krajach azjatyckich, ale również mogą dotykać lokalnych społeczności i samych konsumentów, zwłaszcza gdy produkt jest niebezpieczny dla zdrowia lub przedsiębiorstwo nie wspiera lokalnych społeczności. 
Świadomi zagrożeń ekologicznych i społecznych młodzi konsumenci zaczynają dokonywać zakupów odzieży coraz bardziej odpowiedzialnie oraz oczekują od producentów podejmowania działań z zakresu społecznej odpowiedzialności biznesu. Spełnienie wymagań konsumenta oznacza nierzadko wzrost kosztów związanych ze zmianą źródeł zaopatrzenia, większą kontrolą w łańcuchu dostaw czy wybieraniem surowców z certyfikowanych upraw. Z drugiej strony, wdrażanie zasad CSR w przedsiębiorstwach odzieżowych przynosi producentom szereg korzyści, takich jak poprawa reputacji przedsiębiorstwa, większa lojalność wobec marki oraz preferowanie produktów przedsiębiorstwa w stosunku do produktów konkurencyjnych. Do korzyści z wdrażania CSR można zaliczyć również akceptację przez konsumentów wyższych cen produktów produkowanych zgodnie z zasadami społecznej odpowiedzialności.

Wyniki badania pozwoliły pozytywnie zweryfikować postawione w pracy hipotezy. Świadomi konsumenci, preferujący produkty wytwarzane w sposób społecznie odpowiedzialny, są skłonni zapłacić za nie więcej niż za produkty tradycyjne. Wzrost kosztów wytwarzania związany z wdrażaniem zasad CSR może być zatem rekompensowany wyższą ceną uzyskiwaną przy sprzedaży produktów. Weryfikację hipotezy badawczej oparto na deklaracjach konsumentów, a nie na rzeczywistych wydatkach. Jest to ograniczenie metody badawczej. Należałoby je zatem potwierdzić w eksperymentach rynkowych, mierzących rzeczywiste wydatki konsumentów na odzież.

Literatura

References

Berger-Grabner, D. (2018). Sustainability in Fashion: An Oxymoron?. In: R. Altenburger (ed.), Innovation Management and Corporate Social Responsibility, New York: Springer International Publishing, 171-180.

Bhattacharya, C.B., Sen S., Korschun, D. (2011). Leveraging Corporate Responsibility: The Stakeholder Route to Maximizing Business and Social Value. Cambridge: Cambridge University Press.

Black, I. (2010). Sustainability through Anti-Consumption. Journal of Consumer Behaviour, 9, 403-411.

Bylok, F. (2018). Ethical Consumption and Its Development in Contemporary Society. Problemy Zarządzania, 3(75), 150-165.

Carroll, A.B. (2004). Managing ethically with global stakeholders: A present and future challenge. Academy of Management Executive, 18(2), 114-120.

Freeman, R.E., Harrison, J., Wicks, A., Parmar, B., DeColle, S. (2010). Stakeholder Theory. Cambridge: Cambridge University Press.

Friedman, M. (1970). The Social Responsibility of Business is to Increase Profits. New York Times Magazine, 13.09.1970.

Godfrey, P.C., Merrill, C.B., Hansen, J.M. (2009). The Relationship between Corporate Social Responsibility and Shareholder Value: An Empirical Test of the Risk Management Hypothesis. Strategic Management Journal, 30, 425-445.

Hajdas, M. (2013). Ekologia jako wartość korporacyjna. Rocznik Ochrona Środowiska, 15, 2863-2873.

ISO 26000 (2019, 18 kwietnia). Pozyskano z: www.pkn.pl/iso-26000.

Kumar, V., Christodoulopoulou, A. (2013). Sustainability and branding: An integrated perspective, Industrial Marketing Management, 43, 6-15.

Marcinkowska, M. (2010). Społeczna odpowiedzialność przedsiębiorstw a ich wyniki ekonomiczne aspekty teoretyczne. Przeglad Organizacji, 10, 7-10.

Menz, K.M. (2010). Corporate Social Responsibility: It is Reworded by the Corporate Bond Market? A Critical Note. Journal of Business Ethics, 96, 117-134. 
Palewicz, J., Baran, J. (2012). Organizacja łańcucha dostaw w branży odzieżowej. Logistyka, 6, 531-544. Porter, M., Kramer, M. (2011). Creating shared value. Harvard Business Review, 89(1/2), 62-77.

Porter, M.E., Kramer, M.R. (2006). Strategy and Society. The link between competive adventage and corporate social responsibility. Harvard Business Review, December, 78-92.

Rok, B. (2004). Odpowiedzialny biznes w nieodpowiedzialnym świecie. Akademia Rozwoju Filantropii w Polsce, Warszawa: Wydawnictwo Forum Odpowiedzialnego Biznesu.

Rudnicka, A. (2016). Innowacyjna i odpowiedzialna branża odzieżowa. Logistyka Odzysku, 4, 21-26.

Soppe, A. (2004). Sustainable Corporate Finance. Journal of Business Ethics, 53(1), 213-224.

Stefańska, M. (2013). Podstawy teoretyczne i ewolucja pojęcia społeczna odpowiedzialność biznesu (CSR). Prace Naukowe Uniwersytetu Ekonomicznego we Wrocławiu, Wrocław, 198-211.

Young, W., Hwang, K., McDonald, S., Oates, C. (2010). Sustainable Consumption: Green Consumer Behaviour when Purchasing Products. Sustainable Development, 18, 20-31.

Gomez-Bezares, F., Przychodzen, W., Przychodzen, J. (2016). Bridging the gap: How sustainable development can help companies create shareholder value and improve financial performance. Business Ethics, 26, 1-17.

Zgoda, Z. (2015). Obszary społecznie odpowiedzialnego biznesu. Uwarunkowania zachowań polskich konsumentów. Handel Wewnętrzny, 4(357), 286-295.

Katarzyna Pawlak, dr nauk ekonomicznych w zakresie nauk o zarządzaniu, Wojskowa Akademia Techniczna w Warszawie, Wydział Cybernetyki, Instytut Organizacji i Zarządzania. Ukończyła Uniwersytet Mikołaja Kopernika w Toruniu, gdzie następnie pracowała jako adiunkt w Katedrze Marketingu. Przez kilka lat była adiunktem na Uniwersytecie Technologiczno-Przyrodniczym w Bydgoszczy, a obecnie pracuje jako adiunkt w Instytucie Organizacji i Zarządzania Wojskowej Akademii Nauk. W 2018 r. ukończyła na Uniwersytecie Warszawskim studia podyplomowe z metod statystycznych. Jest przewodniczącą polskiego oddziału (Warszawa) Międzynarodowego Instytutu Inżynierii i Technologii w Hongkongu. Obszary jej zainteresowań to zachowania konsumentów, analiza rynku, badania marketingowe oraz zrównoważony rozwój.

Katarzyna Pawlak, PhD in Economics in the field of management. She has graduated from the Nicolaus Copernicus University in Torun, Poland. She was a lecturer in Marketing Departments both at the Nicolaus Copernicus University in Torun and at the UTP University of Science and Technology in Bydgoszcz. Currently, she works as an assistant professor at the Military University of Technology, Cybernetics Faculty, Organisation and Management Institute. She has also graduated from postgraduate studies in statistical methods at the University of Warsaw. For the past few years she has conducted training courses in customer behaviour, market analysis, marketing research and sustainable development. She is a President of the Polish Branch (Warsaw) of International Engineering and Technology Institute in Hong Kong.

ORCID: 0000-0002-1781-1059

\section{Adres/Address:}

Wojskowa Akademia Techniczna im. Jarosława Dąbrowskiego

Wydział Cybernetyki

Instytut Organizacji i Zarządzania

ul. gen. Sylwestra Kaliskiego 2

00-908 Warszawa 46, Polska

e-mail: katarzyna.pawlak@wat.edu.pl

Anna Dziadkiewicz, dr nauk ekonomicznych w zakresie nauk o zarządzaniu, Uniwersytet Gdański, Wydział Zarządzania, Katedra Marketingu. Ukończyła Uniwersytet Mikołaja Kopernika w Toruniu oraz London School of Economics, a także studia podyplomowe: Menedżer Projektu Badawczo-Rozwojowego, Akademia Trenera Biznesu oraz dwuletnie Europejskie Studia Specjalne 
w Centrum Jeana Monneta przy Wydziale Prawa na UMK w Toruniu. Obecnie jest wykładowcą w Katedrze Marketingu na Uniwersytecie Gdańskim. Jest także właścicielem firmy szkoleniowej AD-futuro. $\mathrm{W}$ ostatnich latach prowadziła szkolenia $\mathrm{w}$ zakresie design management, public relations, marketingu i budowania wizerunku marki. Koordynowała projekty międzynarodowe, a obecnie pełni funkcję głównego kierownika informacji w jednym $\mathrm{z}$ nich. Jej zainteresowania dotyczą podejścia design management i projektowania usług opartego na podejściu design thinking. Jest przewodniczącą polskiego oddziału (Toruń) Międzynarodowego Instytutu Inżynierii i Technologii w Hongkongu.

Anna Dziadkiewicz, PhD in Economics in the field of management. She has graduated from the Nicolaus Copernicus University in Torun, Poland and London School of Public Relations; completed post-graduate studies in the field of Managing Scientific-Research Project, as well as Business Coach Academy and a two-year European studies at Jean Monnet Centre. She is a lecturer in the Marketing Department at the University of Gdansk. She is an owner of a training and consulting company AD-futuro. For the past few years she has conducted training courses in design management, public relations, marketing, enterprise brand building. She has been coordinating a number of international projects and is currently a Head Information Manager in one of them. She is a President of the Polish Branch (Torun) of International Engineering and Technology Institute in Hong Kong. Her interests revolve around design management and service design according to design thinking approach.

ORCID: 0000-0003-1880-4077

\section{Adres/Address:}

Uniwersytet Gdański

Wydział Zarządzania

ul. Armii Krajowej 101

81-824 Sopot, Polska

e-mail: anna.dziadkiewicz@ug.edu.pl 